\title{
The variability of Gentiana pneumonanthe L. subpopulations in different habitat conditions
}

\author{
Kinga Kostrakiewicz-Gieralt \\ Jagiellonian University, Institute of Botany, Department of Plant Ecology, Lubicz 46, \\ 31-512 Kraków, Poland, e-mail: kinga.kostrakiewicz@uj.edu.pl
}

\begin{abstract}
The impact of habitat conditions on the spatio-temporal variability of abundance and structure of subpopulations of Gentiana pneumonanthe L. was investigated in the years 2013-2015 in patches of abandoned Molinion caeruleae meadows in different stages of successional overgrowing (Patches I-III), as well as in a patch of willow thickets (Patch IV). The height of the standing vegetation and soil humidity increased in successive patches, while the light intensity at ground level diminished gradually. Performed observations showed that abundance of subpopulations decreased from Patch I to Patch IV. Seedlings, juvenile and dormant individuals were not found in all subpopulations, whereas the share of vegetative and generative adults differed significantly. The total number of above-ground units per individual, as well as the height of vegetative stems, increased in consecutive years; moreover, it augmented from Patch I to Patch III and it diminished in Patch IV. The height of flowering stalks rose in consecutive years and in successive patches. The numbers of flowers and fruits in consecutive years were rather constant, whilst in successive study sites they augmented gradually.

In light of the performed studies, it might be concluded that the subpopulation occurring in Patch I presents the best state, whereas the subpopulation occurring in Patch IV shows the worst condition and, in the near future, might be eliminated from the colonised site.
\end{abstract}

Key words: abundance, generative stalk, flowers, fruits, structure of individuals, vegetative stem.

\section{Introduction}

Marsch gentian Gentiana pneumonanthe L. belongs to long-lived, polycarpic and nonclonal herbaceous species. The individuals usually produce numerous unbranched vegetative and generative stems. The generative stalks bear insect-pollinated, deeply-blue flowers placed singly on the top or grouped in inflorescences. The fruit is a capsule containing 300-700 minute winged seeds, dispersing by wind usually in August and September and germinating the following spring after natural freezing (Simmonds 1946).

Marsch gentian represents a Eurosiberian subelement occurring in Europe from southern Scandinavia to northern Portugal and eastern Russia (Den Virtuella 1996). Populations of Gentiana pneumonathe occur in wet heathlands, unmanaged grasslands and hay meadows. The aforemen- tioned species belongs to the rare and strictly protected plants in Poland (Regulation of the Minister of Environment... 2014) and is considered as one of most threatened taxa of Polish wetlands (Kopeć \& Michalska-Hejduk 2012). Marsch gentian is included on the Red List of Vascular Plants of Poland (Zarzycki \& Szeląg 2006) and many regional 'red lists' and 'red books' (Jakubowska-Gabara \& Kucharski 1999; Nowak et al. 2008; Bróż \& Przemyski 2009; Babczyńska-Sendek et al. 2012; Podgórska 2014). Moreover, Gentiana pneumonanthe is listed in the Red List of Vascular plants of the Czech Republic (Grulich 2012), Slovakia (Ditě 2009), Hungary (Király 2007), Switzerland (Moser et al. 2002), as well as Great Britain (Cheffings \& Farrell 2005), England (Storh et al. 2014) and Wales (Dines 2008). Furthermore, this species is included in the Red List of Vascular Plants of the Carpathians (Turis et al. 2014). 
The hitherto investigations concerning the march gentian populations have focused on the evaluation of effectiveness of pollination (Petanidou et al. 1995, 2001), the assessment of seed production and seed traits (Oostermeijer et al. 1998) and the observations of germination and seedling recruitment (Křenová \& Lepš 1996). Other researchers have concentrated on the investigations of the fitness of individuals (Oostermeijer et al. 1994b, 1995a), abundance and structure of populations (Chapman et al. 1989; Oostermeijer et al. 1992, 1994a, 1996; Rose et al. 1998; Kesel \& Urban 1999; Kostrakiewicz-Gierałt 2013), as well as the genetic variability of populations (Raijmann et al. 1994; Oostermeijer et al. 1995b).

Despite the gradual growth in the number of studies carried out in populations of Gentiana pneumonanthe in the last three decades, the current state of knowledge is still insufficient and further investigations are still strongly required. Nowadays, the investigations carried out in populations occurring in abandoned meadows subjected to secondary succession seem to be particularly valuable. The results of the aforementioned studies might provide the basis for the programmes necessary for effective, active protection of this endangered species. Taking into account the unsatisfactory state of knowledge, the variability of Gentiana pneumonanthe L. subpopulations along the gradient of successional meadow overgrowing was investigated. The detailed aims concentrated on the assessment of: (i) the abundance and structure of subpopulations, (ii) the structure of size of individuals, (iii) flower and fruit production.

\section{Study area}

The investigations were conducted in Kraków-Kostrze, situated in southern Poland (Fig. 1). The investigations were carried out in patches differentiated by species composition and habitat conditions.

Patches I-III represented Molinion caeruleae association characterised by the presence of Betonica officinalis, Dianthus superbus, Galium boreale, Galium verum, Gladiolus imbricatus, Inula salicina, Iris sibirica, Lotus corniculatus, Selinum carvifolia, as well as Succisa pratensis. Patch I, measuring approximately $700 \mathrm{~m}^{2}$, was dominated by rosette-form species with erect or procumbent stems and delicate underground organs, i.e. Centaurea jacea, Lychnis flos-cuculi and Succisa pratensis. Patch II covered an area of $900 \mathrm{~m}^{2}$; it was prevailed by tall-growing macroforbs such as Sanguisorba officinalis and Lysimachia vylgaris. Patch III, measuring approximately $600 \mathrm{~m}^{2}$, was dominated by large-tussock grasses i.e. Deschampsia caespitosa and Molinia caerulea. Patch IV, covering an area of $1000 \mathrm{~m}^{2}$, represented willow thickets dominated by Salix repens ssp. rosmarinifolia and Salix cinerea.

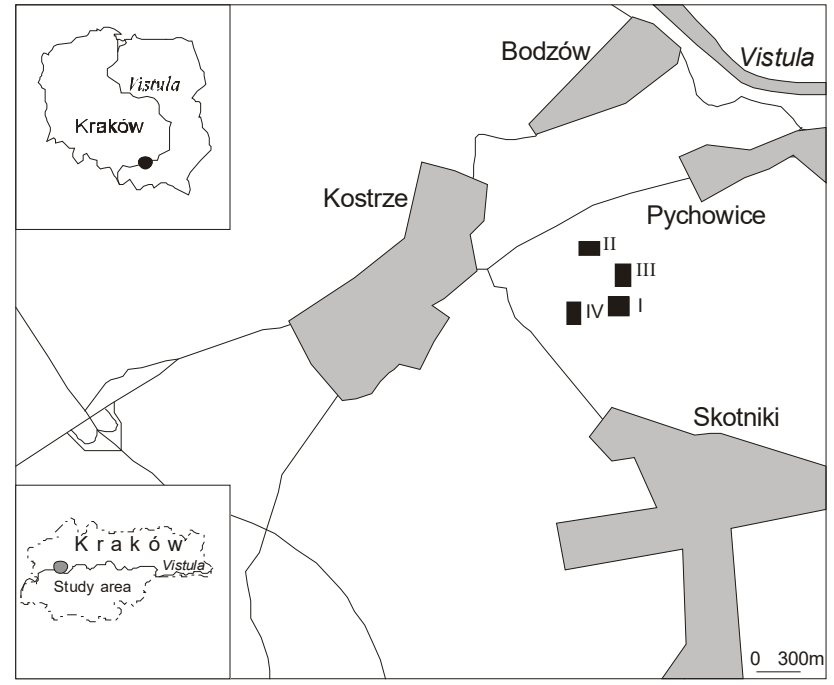

Figure 1. The locality of observed subpopulations of Gentiana pneumonanthe; I- Patch I, II- Patch II, III- Patch III, Iv- Patch IV

\section{Material and methods}

\subsection{Vegetation study}

In all of the above-mentioned patches, the survey of habitat conditions was performed on 8 July 2013. The average height of vascular plants in the patch was evaluated on the basis of measurements of 20 randomly chosen stems of different species (excluding Gentiana pneumonanthe) performed using a folding tape measure. Light intensity at soil level and ground humidity were evaluated on the basis of 20 measurements taken randomly in each patch on 10 July 2013 between 10.00 and 12.00 a.m. Light intensity was examined with a Voltcraft MS-1300 digital light meter (accuracy $\pm 5 \%+10$ digits; range 0.01-50,000 lx). Soil humidity was measured using a BIOWIN soil moisture sensor (range 1-10). The gradual increase of height of plant cover and soil moisture, as well as the decrease of light intensity in consecutive patches, are given in Table 1.

\subsection{Study of Gentiana pneumonanthe L. subpopulations}

In the year 2013, in each of aforementioned patches all individual Gentiana pneumonanthe were inventoried and assigned to the following developmental stages according to Oostermeijer et al. (1994a, b): seedlings (with coltyledones and often with one rosette of leaves), juvenile individuals (with cotyledons and/or one or more vegetative stems with ovate leaves), vegetative adults (with flowerless stems with lance-shaped and revolute leaves), generative adults (both vegetative stems and generative stalks) and dormants 
Table 1. The habitat conditions in observed in observed patches

\begin{tabular}{lcccc}
\hline & Patch I & Patch II & Patch III & Patch IV \\
\hline Patch area $\left(\mathrm{m}^{2}\right)$ & 700 & 900 & 600 & 1000 \\
\hline $\begin{array}{l}\text { Dominants } \\
(\text { cover }>20 \%)\end{array}$ & $\begin{array}{c}\text { Centaurea jacea, } \\
\text { Succisa pratensis, } \\
\text { Lychnis flos-cuculi }\end{array}$ & $\begin{array}{c}\text { Sanguisorba officinalis, } \\
\text { Lysimachia vulgaris }\end{array}$ & $\begin{array}{c}\text { Molinia caerulaea, } \\
\text { Deschampsia caespitosa }\end{array}$ & $\begin{array}{c}\text { Salix repens ssp. } \\
\text { rosmarinifolia, Salix } \\
\text { cinerea }\end{array}$ \\
\hline $\begin{array}{l}\text { Subdominants } \\
\text { (cover 5\%-20\%) }\end{array}$ & $\begin{array}{c}\text { Inula salicina, } \\
\text { Lysimachia vulgaris, } \\
\text { Filipendula ulmaria }\end{array}$ & $\begin{array}{c}\text { Molinia caerulaea, Salix } \\
\text { repens } \text { ssp. rosmarinifolia }\end{array}$ & $\begin{array}{c}\text { Phragmites australis, Salix } \\
\text { repens ssp. rosmarinifolia }\end{array}$ & $\begin{array}{c}\text { Phragmites australis, } \\
\text { Lysimachia vulgaris }\end{array}$ \\
\hline $\begin{array}{l}\text { Mean (range) height } \\
\text { of standing vegetation } \\
(\mathrm{cm})\end{array}$ & $37.9(20-56)$ & $47.7(12-86)$ & $55.7(36-83)$ & $85.9(29-193)$ \\
\hline $\begin{array}{l}\text { Mean (range) soil } \\
\text { humidity (range 1-10) }\end{array}$ & $4.9(3-7)$ & & & $7.2(6-9)$ \\
\hline $\begin{array}{l}\text { Mean (range) light } \\
\text { intensity (lx) }\end{array}$ & 39000 & $6.2(5-8)$ & 30 200 & 26800 \\
\hline
\end{tabular}

(characterised by an absence of any visible above-ground organs during one or two seasons).

Subsequently, within each patch the one representative, permanent study plot ( $15 \mathrm{~m}$ x $15 \mathrm{~m}$ ) was set and fenced. Then, all individuals growing within the study plots were counted and tagged with plastic pegs for further observations, carried out in the years 2013-2015. The investigations conducted on labelled individuals concentrated on the assessment of:

- the total number of above-ground units in all individuals,

- the number and height of all vegetative stems in particular vegetative adults,

- the number and height of all vegetative stems and generative stalks in particular generative adults,

- the number of flowers and fruits created by each generative stalk.

\subsection{Statistical analysis}

The chi-square statistics was applied to check whether there were significant temporal and spatial differences in the percentage of:

- individuals representing diverse developmental stages,

- vegetative adults creating various total number of above-ground units,

- generative adults creating various total number of above-ground units,

- vegetative adults achieving different height of the longest vegetative stem,

- generative adults achieving different height of the longest generative stalk.

Subsequently, normal distribution of the untransformed data of the height of all vegetative stems/generative stalks and number of flowers/fruits in all flowering stalks in an individual sample (from particular patch and year) was tested using the Kolmogorov-Smirnov test, while variance homogeneity was tested using the Levene test at the significance level of $p<0.05$. As the values of individual characteristics in some groups were not consistent with normal distribution and the variance was not homogeneous, the non-parametric Kruskal-Wallis test was used to check the significance of the differences of the aforementioned traits over consecutive years, as well as among successive Patches. All statistical analyses were performed using STATISTICA 10 software.

\section{Results}

The most numerous subpopulation of Gentiana pneumonanthe was found in Patch I, whereas in other Patches a much lower number of individuals were noted $\left(\chi^{2}=242\right.$, $\mathrm{df}=6, \mathrm{P}<0.001)$. Seedlings, juveniles and dormants were not observed in all Patches, whilst the share of vegetative and generative adults in particular subpopulations was different. The rather similar contribution was observed in Patch I, while in Patches II-IV the percentage of generative adults gradually increased (Fig. 2). The structure of size of individuals based on the total number of above-ground units in vegetative and generative adults showed both temporal and spatial variability. In each of the subpopulations the number of stems in vegetative adults significantly increased in consecutive years. Moreover, the number of stems gradually augmented from Patch I via Patch II to Patch III, while in Patch IV it was slightly lower (Fig. 3). Also, in generative adults the total number of vegetative stems and generative stalks increased in consecutive years. Furthermore, the number of above-ground units increased in Patches I-III, while in Patch IV it diminished moderately (Fig. 4). 


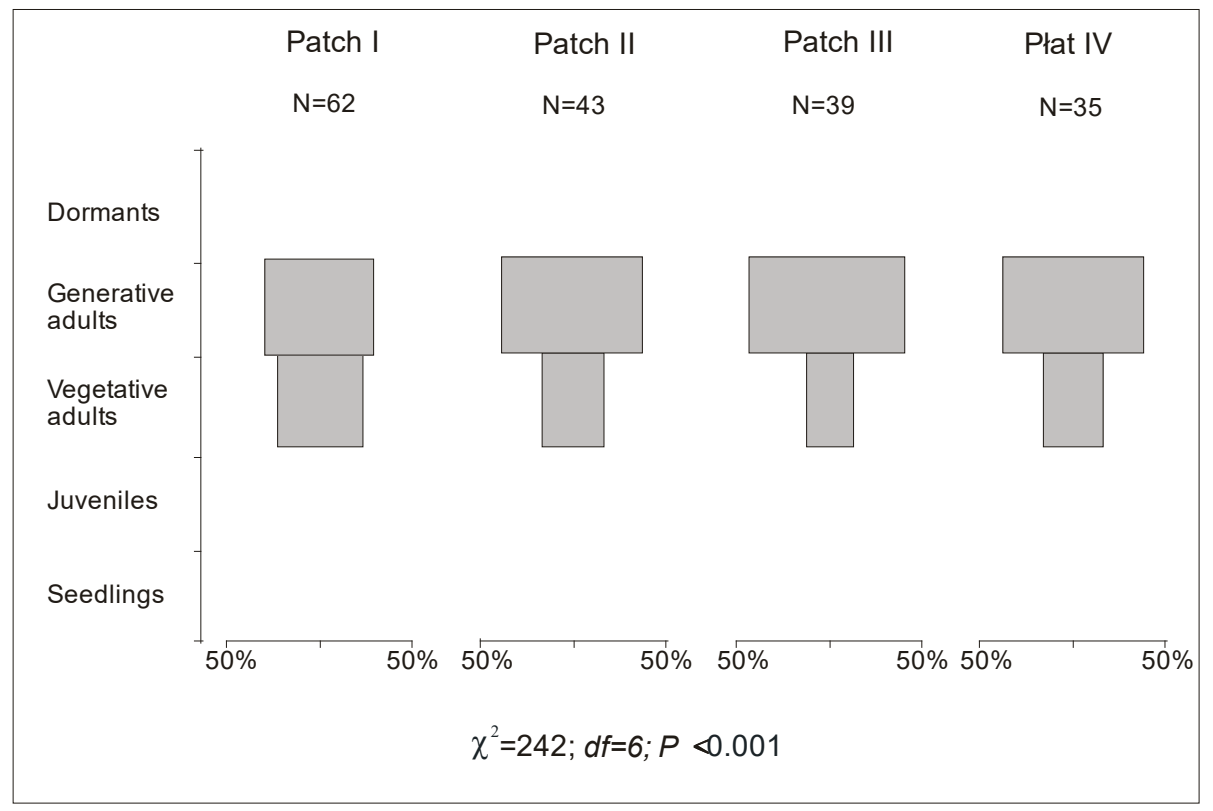

Figure 2. The structure of developmental stages of individuals Gentiana pneumonanthe in studied subpopulations. Axis Y depicts developmental stages, axis X depicts percentage of individuals

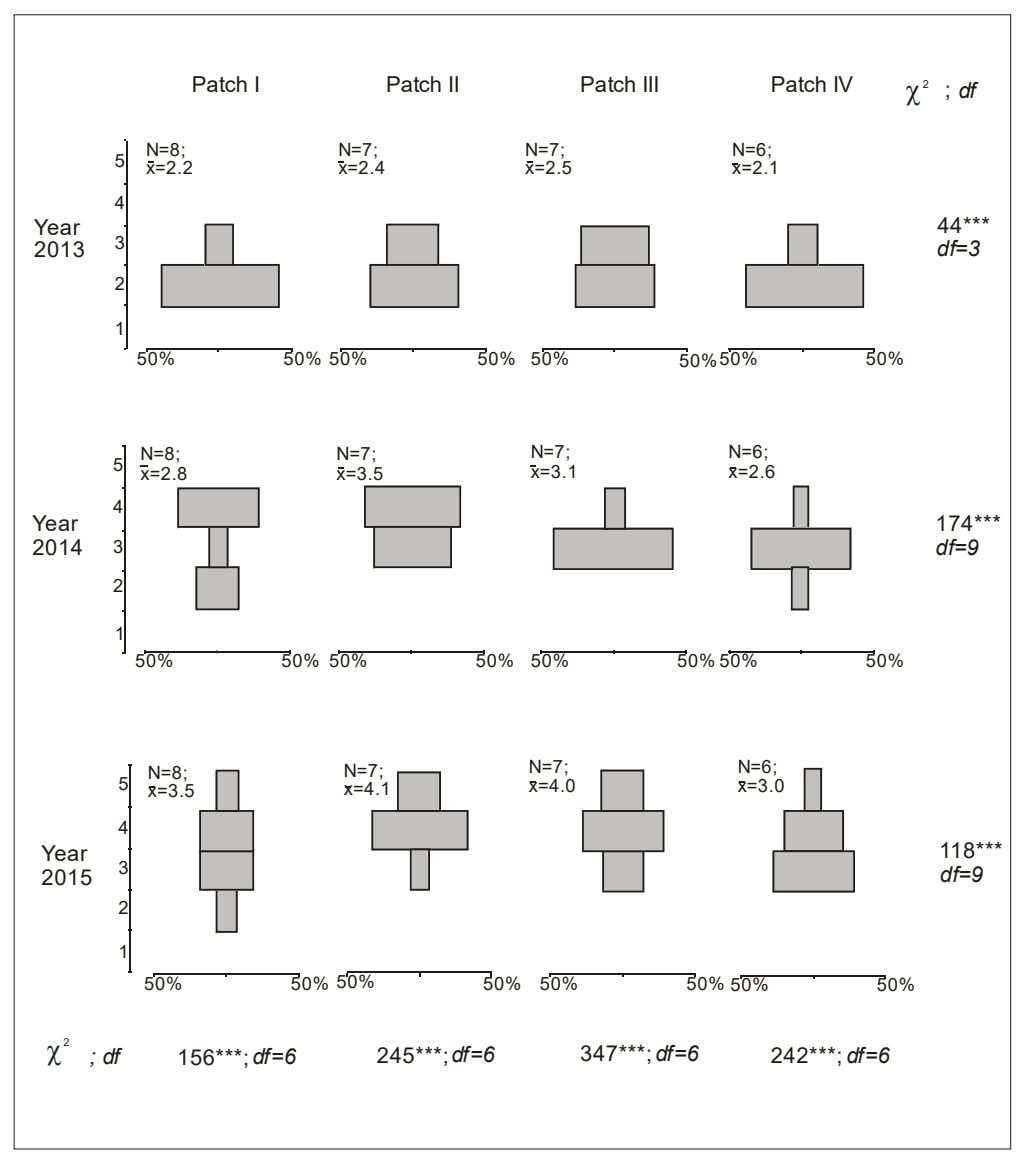

Figure 3. The size structure of vegetative adults Gentiana pneumonanthe in studied subpopulations based on total number of stems. Axis Y depicts number of stems, axis $\mathrm{X}$ depicts percentage of individuals. The level of statistical significance: $* * *<0.0001$ 


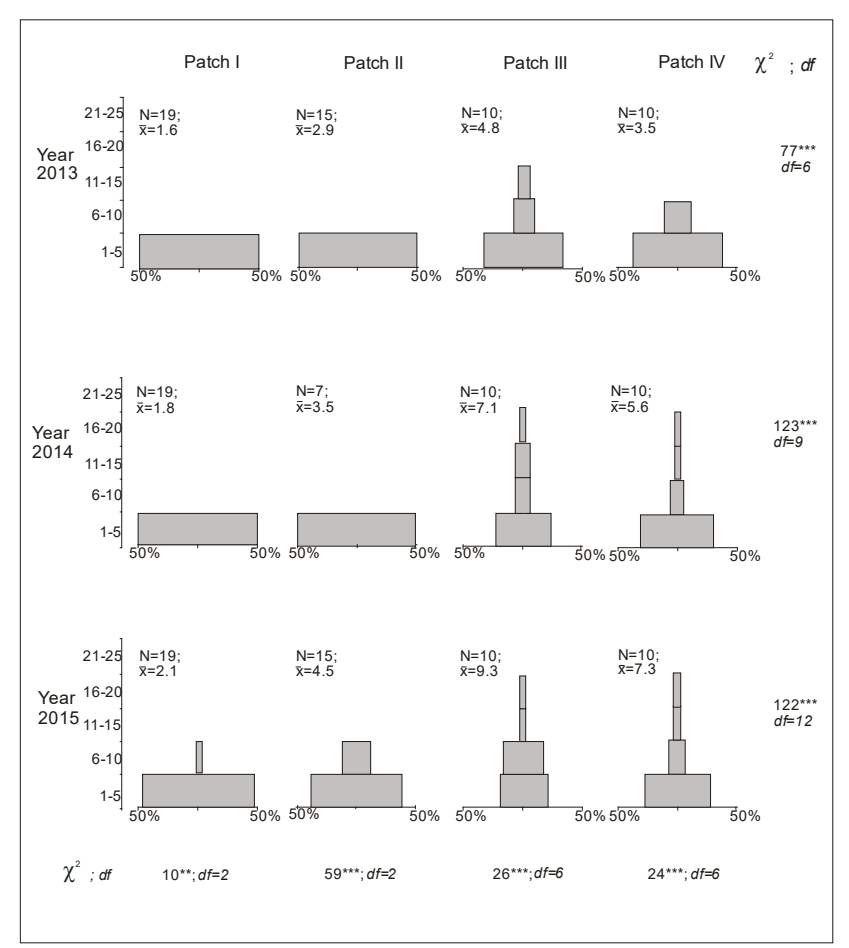

Figure 4. The size structure of generative adults Gentiana pneumonanthe in studied subpopulations based on total number of vegetative stems and flowering stalks. Axis $\mathrm{Y}$ depicts number of stems and stalks, axis $\mathrm{X}$ depicts percentage of individuals. The level of statistical significance: $* * *<0.0001$

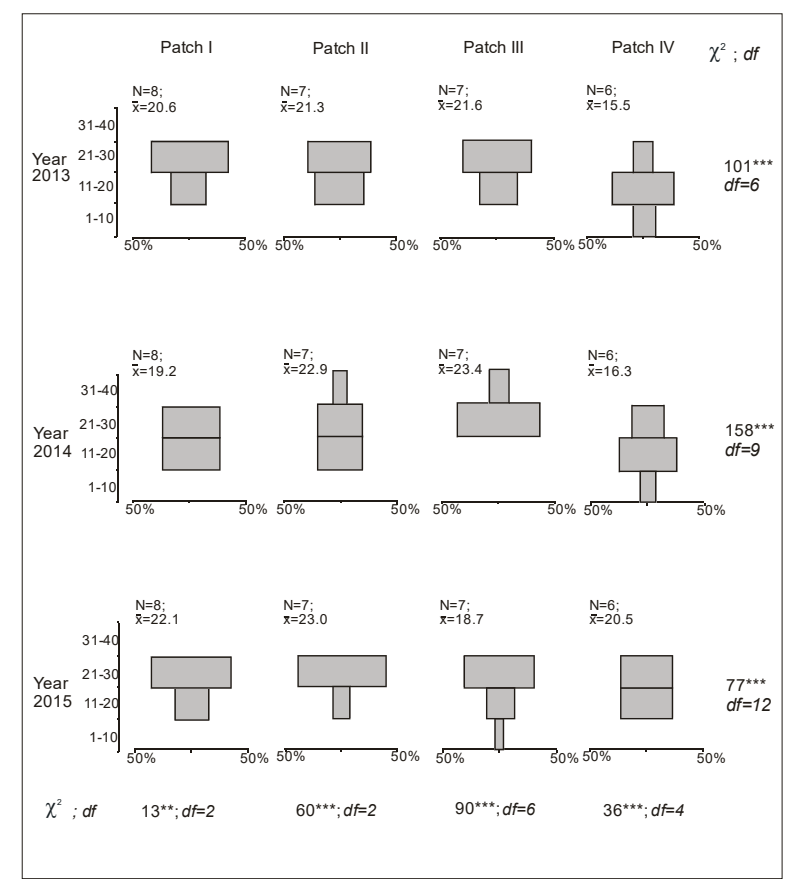

Figure 5. The size structure of vegetative adults Gentiana pneumonanthe in studied subpopulations based on the length of the longest stem. Axis Y depicts length of stems $(\mathrm{cm})$, axis $\mathrm{X}$ depicts percentage of individuals. The level of statistical significance: $* * *<0.0001$

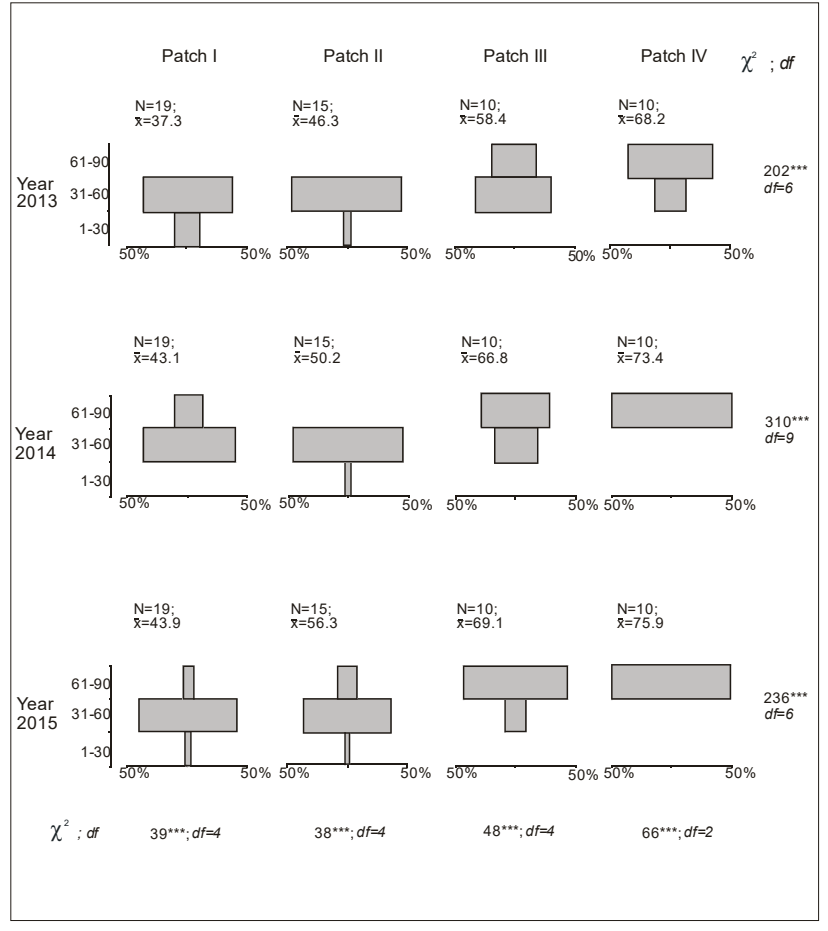

Figure 6. The size structure of generative adults Gentiana pneumonanthe in studied subpopulations based on the length of the longest flowering stalk. Axis Y depicts length of stalks $(\mathrm{cm})$, axis $\mathrm{X}$ depicts percentage of individuals. The level of statistical significance: $* * *<0.0001$

The structure of size of vegetative adults based on the height of the longest stem also presented temporal and spatial variability. In consecutive seasons the height of the longest stems increased in all subpopulations. The height of stems augmented from Patch I via Patch II to Patch III, while in Patch IV it decreased by a small amount (Fig. 5). Similarly, the distribution of height of all vegetative stems differed significantly among consecutive years and in successive Patches (Table 2).

The structure of size of generative adults based on the height of the longest flowering stalk also presented temporal and spatial variability. The height of the longest flowering stalks increased remarkably in consecutive years and in successive patches (Fig. 6). Also, the distribution of height of all flowering stalks showed similar trends (Table 3 ). The production of flowers (Table 4) and number of fruits (Table 5) did not differ in consecutive years, whereas it rose moderately in successive Patches. 
Table 2. The distribution of height of vegetative stems $(\mathrm{cm})$ noted in all vegetative adults occurring in particular Patches; $\mathrm{n}-\mathrm{number}$ of stems

\begin{tabular}{|c|c|c|c|c|c|}
\hline & \multicolumn{4}{|c|}{ The mean (range) height of vegetative stems in: } & \multirow{2}{*}{$\begin{array}{c}\text { The H Kruskal- } \\
\text { Wallis test }\end{array}$} \\
\hline & Patch I & Patch II & Patch III & Patch IV & \\
\hline Year 2013 & $\begin{array}{c}17.5(12-28) \\
\mathrm{n}=18\end{array}$ & $\begin{array}{c}19.4(12-27) \\
n=17\end{array}$ & $\begin{array}{c}19.1(13-27) ; \\
n=16\end{array}$ & $\begin{array}{c}13.1(9-22) ; \\
n=13\end{array}$ & $18.6^{* *}$ \\
\hline Year 2014 & $\begin{array}{c}16.5(11-24) \\
\mathrm{n}=23\end{array}$ & $\begin{array}{c}18.4(12-37) \\
\mathrm{n}=25\end{array}$ & $\begin{array}{c}20.5(12-29) \\
\mathrm{n}=21\end{array}$ & $\begin{array}{c}13.0(7-24) ; \\
n=17\end{array}$ & $29.2 * * *$ \\
\hline Year 2015 & $\begin{array}{c}18.5(10-25) \\
n=28\end{array}$ & $\begin{array}{c}19.8(11-25) \\
\mathrm{n}=29\end{array}$ & $\begin{array}{c}18.3(8-27) \\
\mathrm{n}=28\end{array}$ & $\begin{array}{c}14.1(7-26) ; \\
n=21\end{array}$ & $19.2 * *$ \\
\hline $\begin{array}{l}\text { The } \mathrm{H} \\
\text { Kruskal-Wallis test }\end{array}$ & $6.6^{*}$ & $1.5^{\mathrm{ns}}$ & $1.4^{\mathrm{ns}}$ & $0.2^{\text {ns }}$ & \\
\hline
\end{tabular}

The level of statistical significance: $* \leq 0.05, * *<0.001, * * *<0.0001$, ns - not significant

Table 3. The distribution of height of generative stalks $(\mathrm{cm})$ noted in all generative adults occurring in particular Patches; $\mathrm{n}$ - number of stems

\begin{tabular}{|c|c|c|c|c|c|}
\hline & \multicolumn{4}{|c|}{ The mean (range) height of generative stalks in: } & \multirow{2}{*}{$\begin{array}{c}\text { The H Kruskal-Wallis } \\
\text { test }\end{array}$} \\
\hline & Patch I & Patch II & Patch III & Patch IV & \\
\hline Year 2013 & $\begin{array}{c}37.1(25-51) \\
\mathrm{n}=21\end{array}$ & $\begin{array}{c}44.4(30-54) \\
n=25\end{array}$ & $\begin{array}{c}50.9(31-78) \\
\mathrm{n}=39\end{array}$ & $\begin{array}{c}63.7(43-87) \\
n=22\end{array}$ & $51.3 * * *$ \\
\hline Year 2014 & $\begin{array}{c}41.8(31-69) \\
n=24\end{array}$ & $\begin{array}{c}48.1(30-59) \\
n=30\end{array}$ & $\begin{array}{c}58.9(38-78) \\
\mathrm{n}=59\end{array}$ & $\begin{array}{c}66.4(55-88) \\
n=35\end{array}$ & $76.7^{* * *}$ \\
\hline Year 2015 & $\begin{array}{c}41.6(30-62) \\
n=28\end{array}$ & $\begin{array}{c}53.3(30-72) \\
\mathrm{n}=35\end{array}$ & $\begin{array}{c}63.8(45-87) \\
\mathrm{n}=79\end{array}$ & $\begin{array}{c}69.9(52-89) \\
\mathrm{n}=46\end{array}$ & $98.6^{* * *}$ \\
\hline $\begin{array}{l}\text { The H Kruskal- } \\
\text { Wallis test }\end{array}$ & $0.2^{\mathrm{ns}}$ & $23.4 * * *$ & $40.1 * * *$ & $8.1^{*}$ & \\
\hline
\end{tabular}

The level of statistical significance: $* \leq 0.05, * *<0.001, * * *<0.0001,{ }^{\mathrm{ns}}-$ not significant

Table 4. The number of flowers per generative stalk in particular Patches; $n$ - number of stems

\begin{tabular}{|c|c|c|c|c|c|}
\hline & \multicolumn{4}{|c|}{ The mean (range) number of flowers per generative stalk in: } & \multirow[t]{2}{*}{ The H Kruskal-Wallis test } \\
\hline & Patch I & Patch II & Patch III & Patch IV & \\
\hline Year 2013 & $\begin{array}{c}1.5(1-3) ; \\
n=21\end{array}$ & $\begin{array}{c}1.8(1-3) ; \\
\mathrm{n}=25\end{array}$ & $\begin{array}{c}1.9(1-6) \\
\mathrm{n}=39\end{array}$ & $\begin{array}{c}2.0(1-4) \\
\mathrm{n}=22\end{array}$ & $1.9^{\text {ns }}$ \\
\hline Year 2014 & $\begin{array}{c}1.6(1-3) \\
\mathrm{n}=24\end{array}$ & $\begin{array}{c}1.8(1-4) \\
\mathrm{n}=30\end{array}$ & $\begin{array}{c}2.4(1-6) \\
n=59\end{array}$ & $\begin{array}{c}2.9(1-9) \\
\mathrm{n}=35\end{array}$ & $12.4^{*}$ \\
\hline Year 2015 & $\begin{array}{c}1.7(1-4) \\
n=28\end{array}$ & $\begin{array}{c}1.9(1-4) \\
\mathrm{n}=35\end{array}$ & $\begin{array}{c}3.1(1-6) \\
\mathrm{n}=79\end{array}$ & $\begin{array}{c}2.9(1-9) \\
\mathrm{n}=46\end{array}$ & $26.6^{* * *}$ \\
\hline $\begin{array}{l}\text { The H Kruskal-Wallis } \\
\text { test }\end{array}$ & $0.3^{\mathrm{ns}}$ & $0.1^{\mathrm{ns}}$ & $4.7^{\mathrm{ns}}$ & $3.8^{\mathrm{ns}}$ & \\
\hline
\end{tabular}

The level of statistical significance: ${ }^{*} \leq 0.05,{ }^{*}<0.001,{ }^{*} * * 0.0001,{ }^{\text {ns }}-$ not significant 
Table 5. The number of fruits per generative stalk in in particular Patches; $n$ - number of stems

\begin{tabular}{|c|c|c|c|c|c|}
\hline & \multicolumn{4}{|c|}{ The mean (range) number of fruits per generative stalk in: } & \multirow{2}{*}{$\begin{array}{c}\text { The H Kruskal- } \\
\text { Wallis test }\end{array}$} \\
\hline & Patch I & Patch II & Patch III & Patch IV & \\
\hline Year 2013 & $\begin{array}{c}1.4(1-3) ; \\
n=21\end{array}$ & $\begin{array}{c}1.6(1-3) ; \\
\mathrm{n}=25\end{array}$ & $\begin{array}{c}1.6(1-4) \\
\mathrm{n}=39\end{array}$ & $\begin{array}{c}1.7(1-3) ; \\
n=22\end{array}$ & 1.2 ns \\
\hline Year 2014 & $\begin{array}{c}1.4(1-3) \\
\mathrm{n}=24\end{array}$ & $\begin{array}{c}1.5(1-4) \\
\mathrm{n}=30\end{array}$ & $\begin{array}{c}1.8(1-4) ; \\
\mathrm{n}=59\end{array}$ & $\begin{array}{c}1.7(1-4) \\
\mathrm{n}=35\end{array}$ & $7.8^{*}$ \\
\hline Year 2015 & $\begin{array}{c}1.5(1-3) \\
n=28\end{array}$ & $\begin{array}{c}1.5(1-3) \\
\mathrm{n}=35\end{array}$ & $\begin{array}{c}2.4(1-6) ; \\
n=79\end{array}$ & $\begin{array}{c}2.5(1-7) \\
n=46\end{array}$ & $19.1 * * *$ \\
\hline
\end{tabular}

The level of statistical significance: $* \leq 0.05, * *<0.001, * * *<0.0001,{ }^{\text {ns }}$ - not significant

\section{Discussion}

All the observed subpopulations of Gentiana pneumonanthe might be classified as 'senile' (sensu Oostermeijer et al. 1992) due to the absence of seedlings and juveniles. Such a phenomenon might be the result of a lack of gaps in the plant canopy and litter layer, which are considered as 'safe sites for seedling recruitment'. A similar scenario was previously observed in populations of Gentiana pneumonanthe inhabiting unmanaged meadows (Oostermeijer et al. 1994a, b; Křenová \& Lepš 1996; KostrakiewiczGierałt 2013, 2014a), as well as wet heathlands (Chapman et al. 1989; Kesel \& Urban 1999). Additionally, it should be pointed out that continuous plant cover inhibits the recruitment of generative offsprings of other closely-related species such as Gentiana pannonica (Hofhanzlová \& Fér 2009; Ekrtová \& Košnar 2012), Gentianella germanica (Fischer \& Matthies 1998), as well as Gentianella praecox (Bucharová et al. 2012).

The performed observations showing a substantial increase of the number of above-ground units in vegetative and generative adults in Patches I-III, and then their decrease in Patch IV correspond with previous observations (Kostrakiewicz-Gierałt 2013). The obtained results suggest that tall-growing neighbours, creating robust underground organs, may deteriorate the life conditions and contribute to suppression of the creation of renewing buds, which subsequently develop into vegetative stems and flowering stalks in Gentiana pneumonanthe individuals. A similar phenomenon was observed in the populations of other perennial meadow species Filipendula ulmaria (Falińska 1991, 1995). The increase of the number of shoots Filipendula ulmaria observed in the initial phase of succession in abandoned meadows was inhibited in the terminal stage of succession. The diminishing of the number and growth of above-ground units in a crowded environment observed in herbaceous species was also recorded in trees (Canham et al. 2004). Additionally, it is worth mentioning that competition from neighbours for below-ground resources may force the allocation of biomass to roots at the expense of the shoot (Weiner et al. 1997).

The noted increase of height of stems in vegetative adults from Patch I, via Patch II, to Patch III might be the result of growing lateral shading by adjacent plants, while the lower height of stems in Patch IV might be caused by shading from above created by the willow-shrubs. These findings support the observations of Schmitt et al. (2003), who claimed that shading by neighbouring species reduces energy for photosynthesis, lowers the ratio of red: far red light and, moreover, contributes to stem elongation, which might be suppressed beneath an overhead foliage canopy.

At the same time it should be pointed out that the flowering stalks present a diverse pattern of shade avoidance, which might be connected with its reproductive function. The gradual rise in the dimensions of flowering stems of Gentiana pneumonanthe recorded in consecutive years and in successive patches enables the location of fruits in higher layers of plant cover. According to Tackenberg et al. (2003) the position of seeds seems to be one of the decisive factors in the enhancement of anemochorous dissemination of propagules in new sites. The found increase in height of generative stems in the presented study, as well as number of flowers and fruits in successive patches, supports previous studies carried out in subpopulations of Gentiana pneumonanthe inhabiting abandoned meadows (Kostrakiewicz-Gierałt 2013). A similar phenomenon was also found in other anemochorous, meadow taxa such as Dianthus superbus (Kostrakiewicz-Gierałt 2014b) and Gladiolus imbricatus (Kostrakiewicz-Gierałt 2014c). At the same time it should be mentioned that the observations carried out in other wind-dispersed taxa have documented that the increasing height of adjacent plants decreases the percentage of seeds dispersing beyond neighbouring vegetation and reduces the distance of dispersal (Davies \& Sheley 2007).

In light of the performed studies, it might be concluded that the subpopulation of Gentiana pneumonanthe occurring in Patch I presents the best state due to substantial abundance and occurrence of individuals in prereproduc- 
tive stage, whereas the subpopulation occurring in Patch IV shows the worst condition. The low number of individuals, the slight share of vegetative adults, as well as the lack of gaps in the plant canopy might, in the near future, contribute to the total elimination of the subpopulation from the colonised site.

\section{References}

Babczyńska-Sendek B., Błońska A., Bula R., Cabała S., Hejduk-Michalska D., Hereźniak J., Kołodziejek J., Krajewski Ł, Krause R., Mitka J., Nowak T., Parusel J.B., Piwowarczyk R., Posz E., Siciński J.T., Spałek K., Szendera W., Urbisz A., Urbisz A., Węgrzynek B., Wika S., Wilczek Z. \& Zalewska-Gałosz J., 2012, Czerwona lista roślin naczyniowych województwa śląskiego, [in:] J.B. Parusel (ed.), Czerwone listy wybranych grup grzybów i roślin województwa śląskiego, Centrum Dziedzictwa Przyrody Górnego Śląska, Katowice, Poland: 105-182.

Bróż E. \& Przemyski A., 2009, The red list of vascular plants in the Wyżyna Małopolska Upland (S Poland), [in:] Z. Mirek, A. Nikel (eds), Rare, relict and endangered plants and fungi in Poland, W. Szafer Institute of Botany, Polish Academy of Sciences, Kraków, Poland: 123-136.

Bucharová A., Brabec J. \& Münzbergová Z., 2012, Effect of land use and climate change on the future fate of populations of an endemic species in central Europe, Biological Conservation 145: 39-47.

Canham Ch.D., LePage P.T. \& Coates K.D., 2004, A neighbourhood analysis of canopy tree competition: effects of shading versus crowding, Canadian Journal of Forest Research 34: 778-787.

Chapman S.B., Rose R.J. \& Clarke R.T., 1989, The behavior of populations of the marsch gentian (Gentiana pneumonanthe) - a modeling approach, Journal of Applied Ecology 26(3): 1059-1072.

Cheffings C.M. \& Farrell L., eds, 2005, The Vascular Plant Red Data List for Great Britain, Species Status 7: 1-116, Joint Nature Conservation Committee, Peterborough.

Davies K.W. \& Sheley R.L., 2007, Influence of neighbouring vegetation height on seed dispersal: implications for invasive plant management, Weed Science 55: 626-630.

Den Virtuella Floran, 1996, Klockgentiana Gentiana pneumonanthe L., http://linnaeus.nrm.se/flora/welcome. html [Assessed 30 September 2015)

Dines T., 2008, A Vascular Plant Red Data List for Wales, Plant Life International, Salisbury.

Ditě D., 2009, Červený zoznam ohrozených druchov cievnatých rastlin, http://botany.cz/cs/ohrozene-rastliny-slovenska/
Ekrtová E. \& Košnar J., 2012, Habitat-related variation in seedling recruitment of Gentiana pannonica, Acta Oecologica 45: 88-97.

Falińska K., 1991, Plant demography in vegetation succession, Kluwer Academic Publishers, Dordrecht/Boston/ London.

Falińska K., 1995, Genet disintegration in Filipendula ulmaria: Consequences for population dynamics and vegetation succession, Journal of Ecology 83(1): 9-21.

Fischer M. \& Matthies D., 1998, Experimental demography of the rare Gentianella germanica: Seed bank formation and microsite effects on seedling establishment, Ecography 21: 269-278.

Grulich V., 2012, Red list of vascular plants of the Czech Republic: 3rd edition, Preslia 84: 631-645.

Hofhanzlová E. \& Fér T., 2009, Genetic variation and reproduction strategy of Gentiana pannonica in different habitats, Flora 204: 99-110.

Jakubowska-Gabara J. \& Kucharski L., 1999, Ginące i zagrożone gatunki flory naczyniowej zbiorowisk naturalnych i półnaturalnych Polski Środkowej [Endangered and threatened vascular plants in natural and seminatural communities in Central Poland], Fragmenta Floristica et Geobotanica Polonica 6: 55-74.

Kesel R. \& Urban K., 1999, Population dynamics of Gentiana pneumonanthe and Rhynchospora fusca during wet heathland restoration, Applied Vegetation Science 2(1): 149-156.

Király G., ed., 2007, Red List of the Vascular flora in Hangary. Saját kiadás, Sopron, Hungary.

Kopeć D. \& Michalska-Hejduk D., 2012, How threatened is the Polish wetland flora?, International Journal of Oceanography and Hydrobiology 41(3): 79-89.

Kostrakiewicz-Gierałt K., 2013, The effect of vegetation character on abundance and structure of subpopulations of rare herb species Gentiana pneumonanthe L., Polish Journal of Ecology 61(1): 35-46.

Kostrakiewicz-Gierałt K., 2014a, The effect of neighbouring plant height, disturbance level and gap size on spontaneous recruitment of large-seeded and small-seeded species in Molinietum caeruleae meadows, Polish Journal of Ecology 62(2): 289-306.

Kostrakiewicz-Gierałt K., 2014b, The life-history traits and seedling recruitment of Dianthus superbus L. in different stages of meadow overgrowing, Acta Agrobotanica 67 (2): 23-30.

Kostrakiewicz-Gierałt K., 2014c, The variability of selected features of Gladiolus imbricatus L. in relation to successive stages of meadow communities following the mowing cessation, Polish Journal of Ecology 62(2): 307-321.

Křenová Z. \& Lepš J., 1996, Regeneration of a Gentiana pneumonanthe population in an oligotrophic wet meadow, Journal of Vegetation Science 7(1): 107-112. 
Moser D., Gygax A., Bäumler B., Wyler N. \& Palese R., 2002, Liste Rouge des fougères et plantes à fleurs menacées de Suisse [Red List of threatened ferns and flowering plants of Switzerland], Office fédéral de l'environnement, des forêts et du paysage, Berne, Centre du Réseau Suisse de Floristique, Chambésy, Conservatoire et Jardin botaniques de la Ville de Genève, Chambésy, Série OFEFP “L'environnement pratique”, Switzerland.

Nowak A., Nowak S. \& Spałek K., 2008, Red List of Vascular plants in Opole province, Nature Journal 41: 141158.

Oostermeijer J.G.B., Altenburg R.G.M. \& Den Nijs H.C.M., 1995a, Effects of outcrossing distance and selfing on fitness components in the rare Gentiana pneumonanthe (Gentianaceae), Acta Botanica Neerlandica 44(3): 257-268.

Oostermeijer J.G.B., Brugman M.L., DeBoer E.R. \& DenNijs H.C.M., 1996, Temporal and spatial variation in the demography of Gentiana pneumonanthe, a rare perennial herb, Journal of Ecology 84(2): 153-166.

Oostermeijer J.G.B., den Nijs J.C.M., Raijmann L.E.L. \& Menken S.B.J., 1992, Population biology and management of the marsh gentian (Gentiana pneumonanthe L.), a rare species in the Netherlands, Botanical Journal of the Linnean Society 108(2): 117-130.

Oostermeijer J.G.B., Luijten S.H., Křenová Z.V. \& Den Nijs H.C.M., 1998, Relationships between population and habitat characteristics and reproduction of the rare Gentiana pneumonanthe L., Conservation Biology 12(5): 1042-1053.

Oostermeijer J.G.B., van Eijck M.W., van Leeuwen N.C. \& den Nijs J.C.M., 1995b, Analysis of the relationship between allozyme heterozygosity and fitness in the rare Gentiana pneumonanthe L., Journal of Evolutionary Biology 8(6): 739-757.

Oostermeijer J.G.B., Van Neijck M.W. \& Den Nijs H.C.M., $1994 b$, Offspring fitness in relation to population size and genetic variation in the rare perennial plant species Gentiana pneumonanthe (Gentianaceae), Oecologia 97(3): 289-296.

Oostermeijer J.G.B., Van't Veer R. \& Den Nijs J.C.M., 1994a, Population structure of the rare, long-lived perennial Gentiana pneumonanthe L. in relation to vegetation and management in the Netherlands, Journal of Applied Ecology 31: 428-438.

Petanidou T., Den Nijs J.C.M., Oostermeijer J.G.B. \& Ellis-Adam A.C., 1995, Pollination ecology and patch-dependent reproductive success of the rare perennial Gentiana pneumonanthe L., New Phytologist 129(1): 155-163.

Petanidou T., Ellis-Adam A., Den Nijs H.C.M. \& Oostermeijer J.G.B., 2001, Differential pollination success in the course of individual flower development and flowering time in Gentiana pneumonanthe L. (Gentianaceae), Botanical Journal of Linnean Society 135(1): 25-33.
Podgórska M., 2014, Zagadnienia geobotaniczne Garbu Gielniowskiego. Część V. Wartości florystyczne. Lokalna czerwona lista roślin naczyniowych [Geobotanical problems of the Garb Gielniowski Hummock. Part V. Floristic values. The local red list of vascular plants], Fragmenta Floristica et Geobotanica Polonica 21(2): 305-322.

Raijmann L.E.L., Van Leeuwen N.C., Kersten R., Oostermeijer J.G.B., Den Nijs H.C.M. \& Menken S.B.J., 1994 , Genetic variation and outcrossing rate in relation to population size in Gentiana pneumonanthe L., Conservation Biology 8(4): 1014-1026.

Rose R.J., Clarke R.T. \& Chapman S.B., 1998, Individual variation and the effects of weather, age and flowering history on survival and flowering of the long-lived perennial Gentiana pneumonanthe, Ecography 21(3): 317-326.

Rozporządzenie Ministra Środowiska z dnia 9.10.2014 r. o ochronie gatunkowej roślin (Dz.U. RP 2014, poz. 1409) [Regulation of the Minister of the Environment of 9 October 2014 on the species-specific protection of plants (Dz. U. RP [Journal of Laws RP] 2014, item 1409)], 2014, Kanc. Prezesa Rady Min., Warszawa.

Schmitt J., Stinchcombe1 J.R., Heschel M.S. \& Huber H., 2003, The adaptive evolution of plasticity: phytochrome-mediated shade avoidance responses, Integr. Comp. Biol. 43 (3): 459-469.

Simmonds N.W., 1946, Gentiana pneumonanthe L., Journal of Ecology 33(2): 295-307.

Stroh P.A., Leach S.J., August T.A., Walker K.J., Pearman D.A., Rumsey F.J., Harrower C.A., Fay M.F., Martin J.P., Pankhurst T., Preston C.D. \& Taylor I., 2014, A Vascular Plant Red List for England, Botanical Society of Britain and Ireland, Bristol, England.

Tackenberg O., Poschlod P. \& Bonn S., 2003, Assessment of wind dispersal potential in plant species, Ecological Monographs 73: 191-205.

Turis P., Eliáš P. (jun.), Schmotzer A., Király G., Schneider E., Kuciel H., Szewczyk M., Kozurak A., Antosyak T., Voloshchuk M., Lazarević P. \& Lustyk P., 2014, Red List of Vascular Plants of Carpathians, [in:] J. Kadlečík (ed.), Draft Red Lists of Threatened Carpathian Habitats and Species and Carpathian List of Invasive Alien Species, The State Nature Conservancy of the Slovak Republic, Banská Bystrica, Slovakia.

Weiner J., Wright D.B. \& Castro S., 1997, Symmetry of belowground competition between Holcus lanatus and Dactylis glomerata, Oikos 79: 85-91.

Zarzycki K. \& Szeląg Z., 2006, Red List of Vascular Plants in Poland, [in:] Z. Mirek, K. Zarzycki, W. Wojewoda, Z. Szeląg (eds), Red List of Vascular Plants and Fungi in Poland, W. Szafer Polish Academy of Sciances, Institute of Botany, Kraków, Poland: 9-32. 